\title{
The Expression of the Growth Associated Protein B50/GAP43 in the Olfactory System of Neonatal and Adult Rats
}

\author{
J. Verhaagen, ${ }^{1}$ A. B. Oestreicher, ${ }^{2}$ W. H. Gispen, ${ }^{2}$ and F. L. Margolis ${ }^{1}$ \\ 'Department of Neurosciences, Roche Institute of Molecular Biology, Roche Research Center, Nutley, New Jersey 07110 , \\ and ${ }^{2}$ Division of Molecular Neurobiology, Rudolf Magnus Institute for Pharmacology and institute of Molecular Biology and \\ Medical Biotechnology, University of Utrecht, $3584 \mathrm{CH}$ Utrecht, The Netherlands
}

\begin{abstract}
B50/GAP43 is a neuron-specific phosphoprotein whose expression is associated with neural development and synaptic plasticity. Its postnatal ontogeny was investigated in the primary olfactory pathway of the rat using immunohistochemical methods. The unique ability of the olfactory neuroepithelium to generate new neurons from a population of precursor cells present in the basal cell layer of this tissue makes it a valuable model in the study of neural development. In newborn rats B50/GAP43 is present throughout the entire population of olfactory receptor neurons. These cells are stained throughout, from the ciliated dendritic knob to their axon terminals in the bulb. This appears to be the first example of unambiguous B50/GAP43 expression in dendritic processes. With increasing age the distribution of this protein becomes progressively restricted to a subpopulation of olfactory neurons. Comparison of the expression of B50/ GAP43 and the olfactory marker protein (OMP), a polypeptide only present in mature olfactory neurons, revealed that during postnatal development of the olfactory system these 2 proteins are expressed in a nearly reciprocal fashion. In adult animals ( 3.5 months -6 months of age), B50/GAP43positive cells are exclusively present adjacent to the basal cell layer of the neuroepithelium. Basal cells appear to be unstained. The region of the epithelium containing the B50/ GAP43-positive cells is virtually devoid of OMP-positive neurons. A significant fraction of these B50/GAP43-containing cells bear dendritic and neuritic processes. However, these cells do not express olfactory cilia. It is probable that the olfactory neurons expressing the growth-associated B50/ GAP43 protein may correspond to a particular subset of olfactory neurons at an intermediate state of maturation.
\end{abstract}

The olfactory neuroepithelium has been the subject of numerous studies addressing questions related to mechanisms operative in neuronal plasticity. This is largely due to the unique ability of the adult olfactory epithelium to generate new neurons from a population of precursor cells present in the basal cell layer of the neuroepithelium. Division and differentiation of these precursor cells occurs throughout life in all vertebrates examined (Graziadei and Monti Graziadei, 1978). The concept of continued turnover of receptor neurons derives from (1) the observation that a developmentally heterogeneous population of

\footnotetext{
Received May 27, 1988; revised July 28, 1988; accepted July 29, 1988.

We thank Dr. W. H. Halliwell for helpful discussions and reviewing the manuscript. Ms. Janet Becker is acknowledged for her technical assistance.

Correspondence should be addressed to F. L. Margolis at the above address.

Copyright (C) 1989 Society for Neuroscience $0270-6474 / 89 / 020683-09 \$ 02.00 / 0$
}

receptor neurons is present in adult animals, and (2) autoradiographic studies that have demonstrated that neuroblast-like cells in the basal cell layer of olfactory epithelium of mature rodents incorporate ${ }^{3} \mathrm{H}$-thymidine. These labeled cells progressively advance to more superficial regions of the epithelium to become mature receptor neurons. This process can be accentuated following surgical or chemical damage to the mature neurons, resulting in their death and subsequent replacement from the progenitor cell compartment (Costanzo and Graziadei, 1983; Samanen and Forbes, 1984).

The specific molecular events that underlie the exceptional neurogenic capacity of the olfactory receptor cell precursors are largely unknown. Maturation of the olfactory neuroepithelium is paralleled by a progressive increase in the number of neurons containing the olfactory marker protein (OMP; Margolis, 1972, 1988) and expressing olfactory cilia (Chuah et al., 1985). The OMP-containing cells are absent from the basal cell layer of the olfactory epithelium in the adult animal and OMP is expressed only 7-8 d after the last ${ }^{3} \mathrm{H}$-thymidine incorporation (Farbman and Margolis, 1980; Miragall and Monti Graziadei, 1982). These observations indicate that OMP is only expressed in olfactory neurons that have reached a relatively advanced state of maturation. The phenotypic diversity of olfactory receptor cells at various stages of maturation also became apparent in studies with monoclonal antibodies raised in mice using crude epithelial homogenates as the immunogen (Allen and Akeson, 1985a, b; Fujita et al., 1985; Hempstead and Morgan, 1985). With some of these antibodies, it was possible to discriminate between receptor cells in the basal and neuronal cell layers of the mature neuroepithelium. However, the antigens recognized by these antibodies are only beginning to be characterized.

The purpose of this study was to provide insight into the dynamics of the olfactory epithelium during postnatal development and in the adult rat, using antibodies directed against B50/GAP43, a well-characterized neuron-specific phosphoprotein. Recent cloning experiments have demonstrated that this $24 \mathrm{kDa}$ membrane-associated protein has been studied from different perspectives in several laboratories using a variety of designations (Basi et al., 1987; Cimler et al., 1987; Karns et al., 1987; Nielander et al., 1987; Rosenthal et al., 1987; reviewed by Benowitz and Routtenberg 1987). Thus, B50, a protein kinase C-substrate implicated in polyphosphoinositide turnover; GAP43 and GAP48 proteins with an axonal growth-related expression pattern; protein $F_{1}$, a phosphoprotein associated with long-term potentiation in hippocampal neurons; pp46, a phosphoprotein of growth cone membranes; and P57, a neuronspecific calmodulin binding protein are identical. For convenience we will refer to the protein as B50/GAP43 in this paper. 
Thc growth-rclatcd appcarancc of B50/GAP43 in ncurons has previously been established using ${ }^{35} \mathrm{~S}$-methionine pulse-labeling (Benowitz et al., 1981; Skene and Willard, 1981) and immunochemical methods (De Graan et al., 1985; Jacobson et al., 1986; Meiri et al., 1986; Oestreicher and Gispen, 1986; Skene et al., 1986; Van Hooff et al., 1986; Verhaagen et al., 1986, 1988a). It appears that the developmental regulation of B50/ GAP43 expression takes place largely at the level of gene transcription (Basi et al., 1987; Karns et al., 1987; Nielander et al., 1987; Rosenthal et al., 1987).

In this report we demonstrate that B50/GAP43 and OMP are differentially expressed in the olfactory neuroepithelium during postnatal development. B50/GAP43 is expressed in the total population of olfactory neurons in the neonatal rat, very few of which express OMP. In young, sexually mature rats B50/GAP43 is virtually absent from the neuronal cell layer containing the mature OMP-immunoreactive receptor cells. However, in adult rats a limited number of cells located near the basal cell layer of the epithelium clearly expressed B50/GAP43 throughout the cell, including the axonal and peripheral dendritic processes. In view of the well-known property of B50/GAP43 to appear in neurons elaborating axonal processes, the latter observation is consistent with olfactory receptor cell differentiation throughout the life of the animal. A preliminary account of this work has been presented (Verhaagen et al., 1988b).

\section{Materials and Methods}

Immunohistochemistry was conducted on olfactory epithelia and olfactory bulb tissue from Sprague-Dawley derived CD rats (Charles River Breeding Laboratories) born in our vivarium and sacrificed at various times after birth. Three animals were taken at each time point.

At postnatal days 1,3 , and 9 , the tissues were dissected from decapitated rats and immersion-fixed at $4^{\circ} \mathrm{C}$ for $24 \mathrm{hr}$ in PLP (2\% paraformaldehyde, $0.75 \mathrm{M}$ lysine, $0.2 \%$ sodium periodate in $50 \mathrm{~mm}$ phosphate buffer, pH 7.4; McLean and Nakane, 1974). The animals sacrificed 3.5, 5 , and 7 weeks and 3.5 and 6 months after birth were perfusion-fixed under Nembutal anesthesia with the same fixative. Following anesthesia these rats were first perfused with 50-100 ml PBS, pH 7.4, and subsequently with PLP ( $2 \mathrm{ml}$ PLP/gm body weight). Olfactory turbinates and bulbs were dissected en bloc and posttixed for 1-2 hr in PLP at $4^{\circ} \mathrm{C}$. The tissues of all animals were decalcified overnight in $250 \mathrm{~mm}$ EDTA/ 50 mm phosphate buffer, $\mathrm{pH} 7.4$, and cryoprotected by immersion in graded sucrose $(7.5-15-30 \%)$ solutions at $4^{\circ} \mathrm{C}$.

Ten-micron-thick cryostat sections, mounted on formol-gelatin-coated microscope slides, were soaked in PBS containing $0.2 \%$ Triton X-100 (PBS/TX-100) for $15 \mathrm{~min}$. Subsequently, sections were incubated overnight at room temperature with goat anti-OMP-antiserum (Keller and Margolis, 1975), affinity-purified rabbit anti-B-50-IgG (Oestreicher et al., 1983), or normal rabbit IgG (Dakopatts, Denmark). Antibodies were diluted in PBS/TX-100 containing 0.2\% BSA. After several washes in PBS/TX-100, the site of antigen-antibody binding was visualized with an avidin/biotin/HRP-staining kit (Vector Laboratories, Burlingame, CA), according to the procedure supplied with the kit. Tissue sections were examined on an Olympus RB-2 light microscope and photographed using 100 ASA Kodak TMAX black-and-white film.

The specificity of the affinity-purified anti-B-50-IgG was confirmed by evaluation on immunoblots and shown to give a single band with extracts of olfactory neuroepithelium, olfactory bulb, and total CNS (J. Verhaagen and F. I. Margolis, unpublished observations).

\section{Results}

\section{Olfactory epithelium}

On postnatal days 1, 3, and 9 B50/GAP43-immunoreactive neurons were present throughout the entire olfactory epithelium (Fig. 1, A, C). B50/GAP43 immunoreactivity was observed in the cell bodies, apical dendrites, and descending neuritic processes of the nerve cells. Olfactory knobs and proximal portions of olfactory cilia were intensely stained during this stage of development (Fig. 2, $A, B$ ). The axonal processes formed small nerve bundles in the lamina propria mucosae adjacent to the neuroepithelium, and these nerve bundles collected into heavily immunostained fascicles (Fig. 3A). On postnatal day 1 OMP was present in a small number of neurons occupying a welldefined superficial region of the ncuroepithelium. The OMPpositive neurons constituted a discontinuous band of single cells at this age (Fig. 1 $B$ ). The numbers of OMP-immunoreactive cells increased progressively with age, and the OMP-containing cell layer increased in thickness from about 1 cell at postnatal day 1 to $3-4$ cells at postnatal day 9 (Fig. $1, B, D$ ). A patchy pattern of OMP immunoreactivity could be seen in the nerve bundles in the lamina propria mucosae (Fig. $3 B$ ).

In 3.5- and 5-week-old rats the most intensely stained B50/ GAP43-positive cells were located in the lower half of the epithelium, while only faint B50/GAP43 immunoreactivity occurred in neurons in the upper compartment of the epithelium. In 7-week-old rats the olfactory epithelium was virtually devoid of B50/GAP43-positive receptor cells (Fig. 1G). During the 3.57 week period OMP immunoreactivity was present in several layers of receptor neurons, but the deepest region of the epithelium, which contained a gradually decreasing number of B50/ GAP43 immunoreactive cells, remained nearly devoid of OMP staining.

In the adult rats (3.5 and 6 months of age) B50/GAP43immunoreactive cell bodies are observed adjacent to the basal cell layer of the epithelium exclusively. These B50/GAP43-containing cells appeared either in small groups or as individual cells so that some areas of the basal cell region were devoid of B50/GAP43-positive cells (Fig. $1 I$ and 2D). A considerable number of B50/GAP43-positive cells in the basal cell region of adult rats formed dendritic and neuritic processes. Often the dendritic processes reached the surface of the epithelium and formed a dendritic knob (Fig. $1 I ; 2, C, D$ ). However, in contrast to the olfactory knobs in young rats, the knobs of the 3.5- and 6-month-old rats never bore B50/GAP43-positive olfactory cilia (Fig. 2C).

In the 3.5- to 7-week-old rats the pattern of B50/GAP43 immunoreactivity in the nerve bundles tended to change from a homogeneous staining of the total cross section of the nerve bundles to a patchy staining pattern. In the 3.5 - and 6-monthold animals this typical patchy distribution of B50/GAP43 immunoreactivity was evident in the majority of nerve bundles and was clearly distinct from the nearly homogeneous staining obtained with OMP antibodies (Fig. 3, E, F).

Incubation of sections with normal rabbit IgG instead of affinity-purified B50/GAP43 IgG resulted only in an overall faint background staining of the tissue.

\section{Olfactory bulb}

Incubation of olfactory bulb tissue sections with anti-B50/GAP43 and anti-OMP antibodies resulted in staining of the olfactory nerve layer and glomeruli in a strikingly similar fashion during the early stages of development (Fig. 4). During the 1-9 d postnatal period, glomeruli increased in size and at 3 and $9 \mathrm{~d}$ the glomeruli were visible as intensely labeled globular structures that were clearly separated from the olfactory nerve layer. Between 3.5 weeks and 6 months after birth B50/GAP43 immunoreactivity in the nerve layer and the glomeruli declined. In rats 6 months of age patchy staining was observed in the nerve 

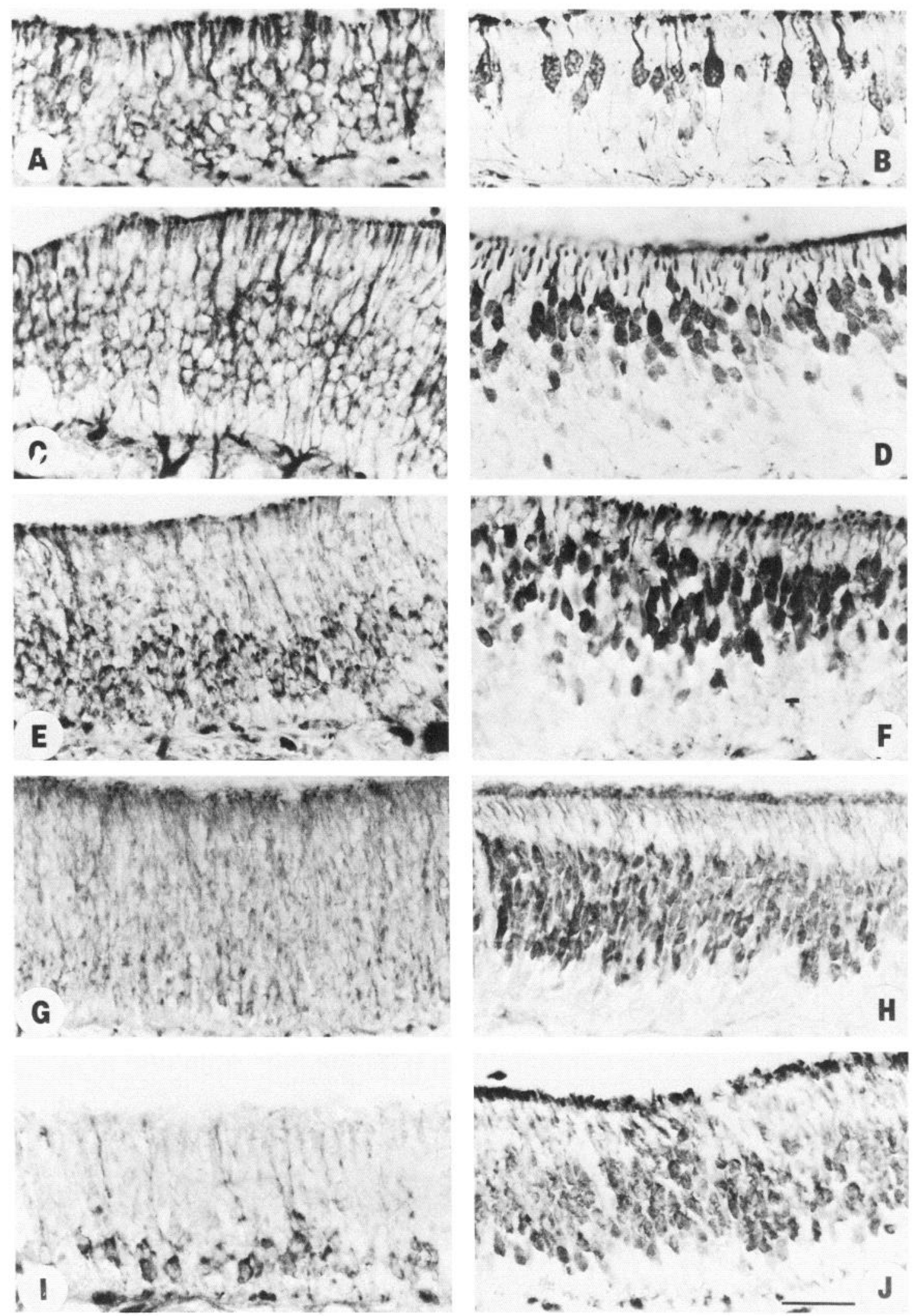

Figure 1. Immunohistochemical localization of B50/GAP43 and OMP in rat olfactory epithelium. B50/GAP43 $(A, C, E, G, I)$ and OMP $(B, D$, $F, H, J)$ in rats at the following ages: $1 \mathrm{~d}(A, B), 9 \mathrm{~d}(C, D), 3.5$ weeks $(E, F), 7$ weeks $(G, H)$, and 6 months $(I, J)$. The nearly reciprocal relationship between B50/GAP43 and OMP expression is evident. The different character of the staining between OMP and B50/GAP43 as seen in the mucosa is related to the fact that OMP is strictly cytoplasmic, while B50/GAP43 is largely membrane associated. Scale bar, $50 \mu \mathrm{m}$. 


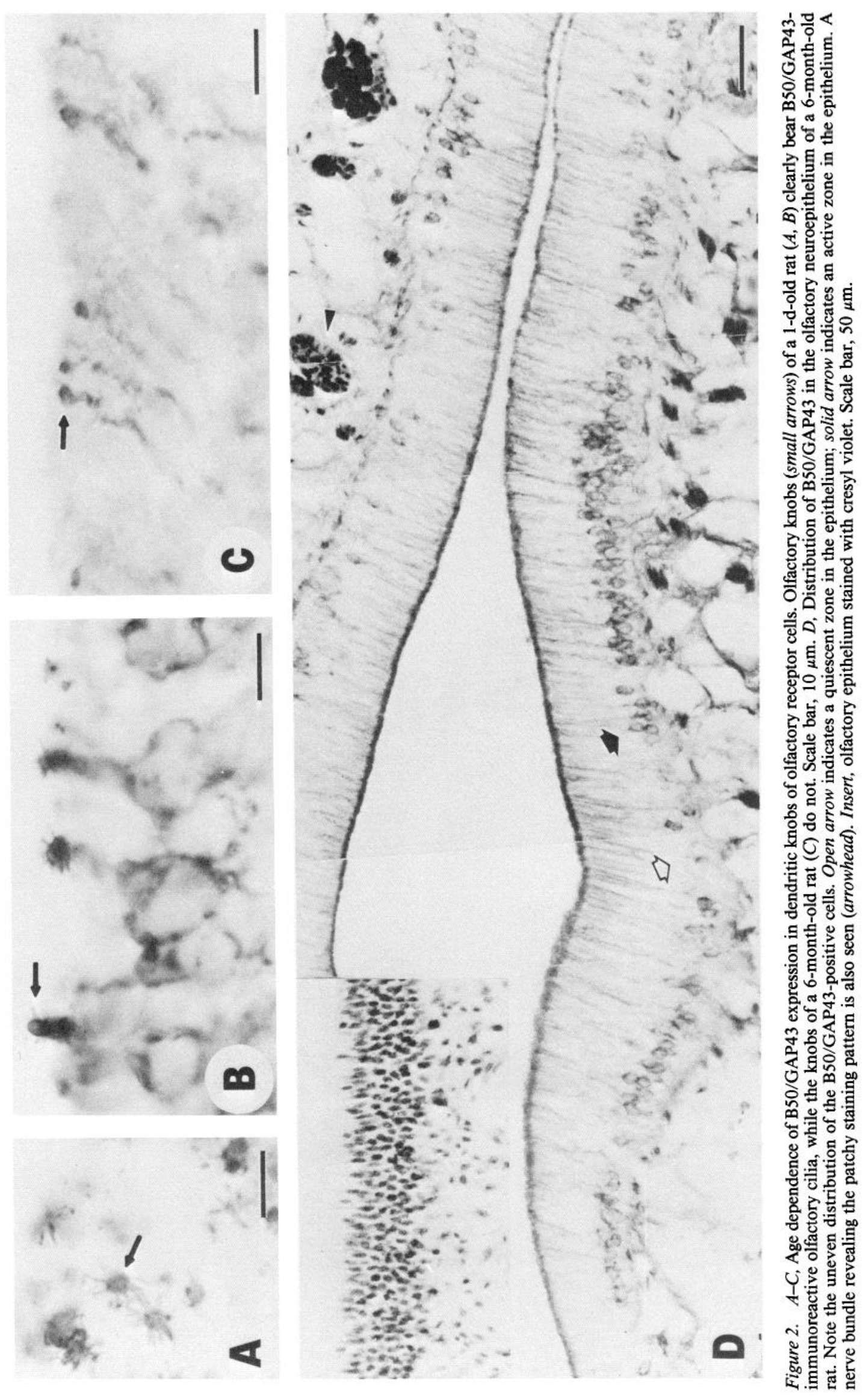



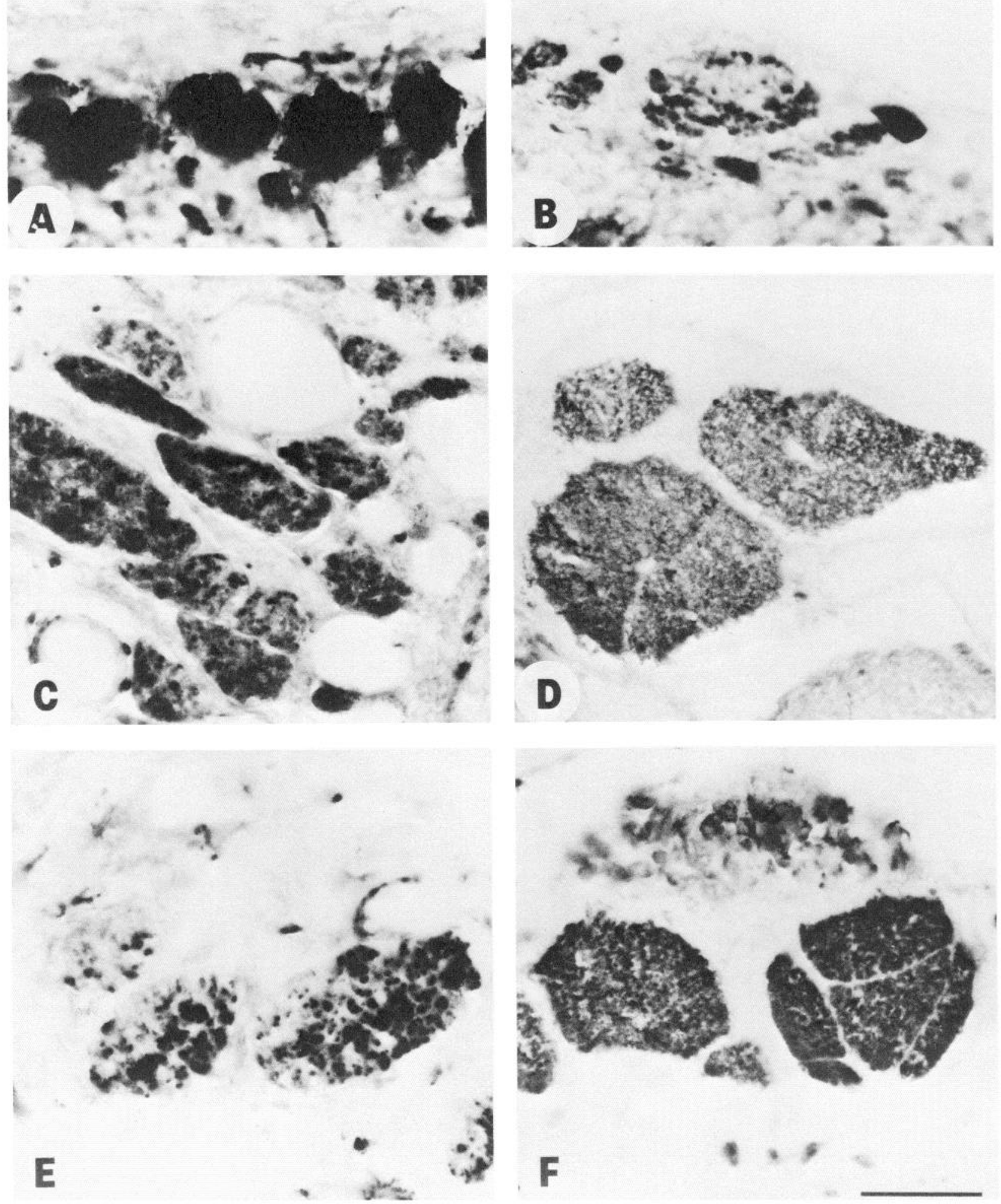

Figure 3. Ontogeny of B50/GAP43 and OMP expression in olfactory nerve bundles in the lamina propria mucosae. B50/GAP43 ( $A, C, E)$ and the OMP $(B, D, F)$ staining is shown in rats aged $1 \mathrm{~d}(A, B), 7$ weeks $(C, D)$, and 6 months $(E, F)$. Note the typical patchy staining in the nerve bundles for B50/GAP43 in the 6-month-old rat and for OMP in the 1-d-old rat. These staining patterns presumably represent the ingrowth into the fascicles of a limited number of B50/GAP43 and OMP containing axons during these particular stages of development. Scale bar, $50 \mu \mathrm{m}$. 

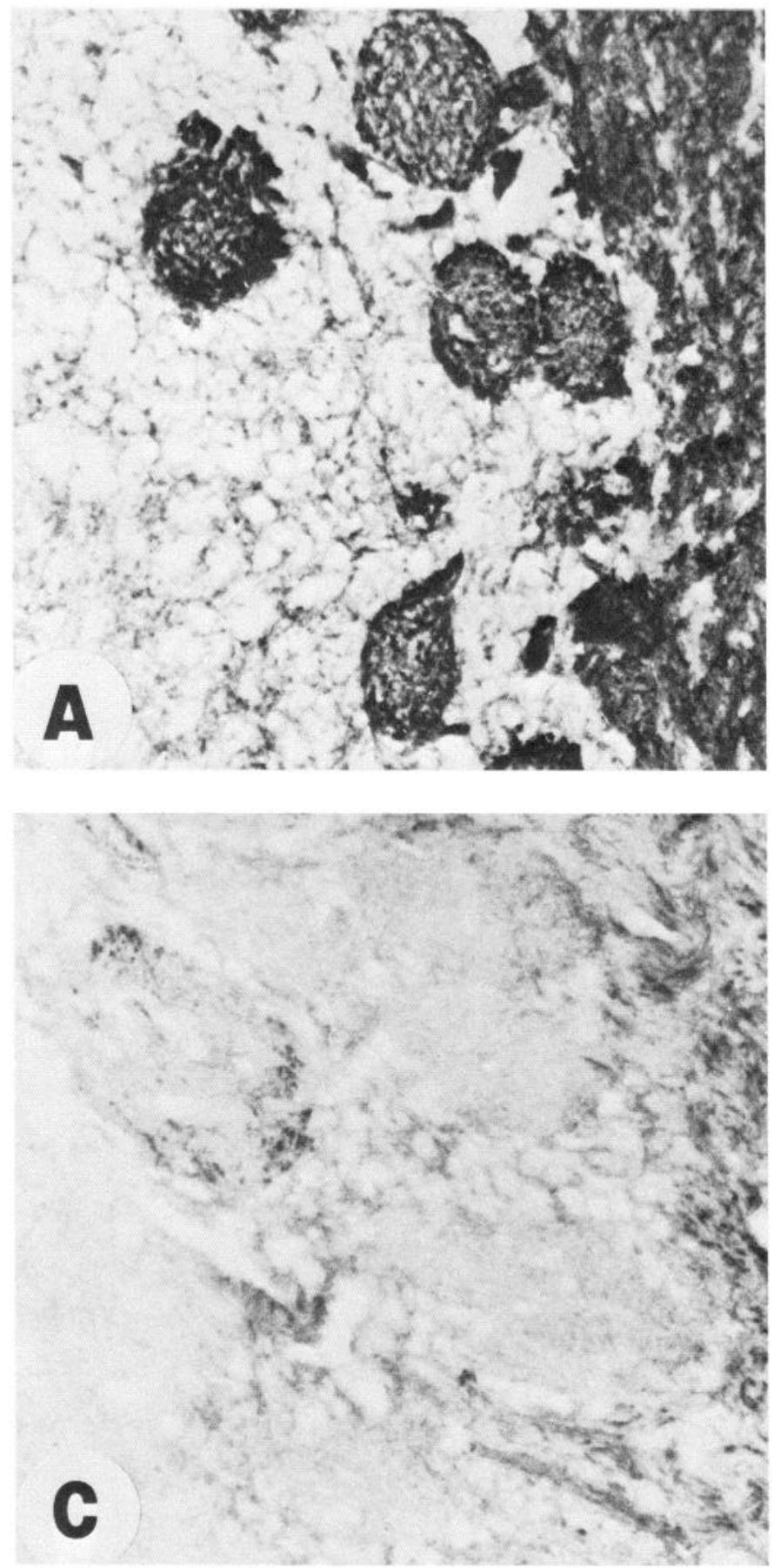
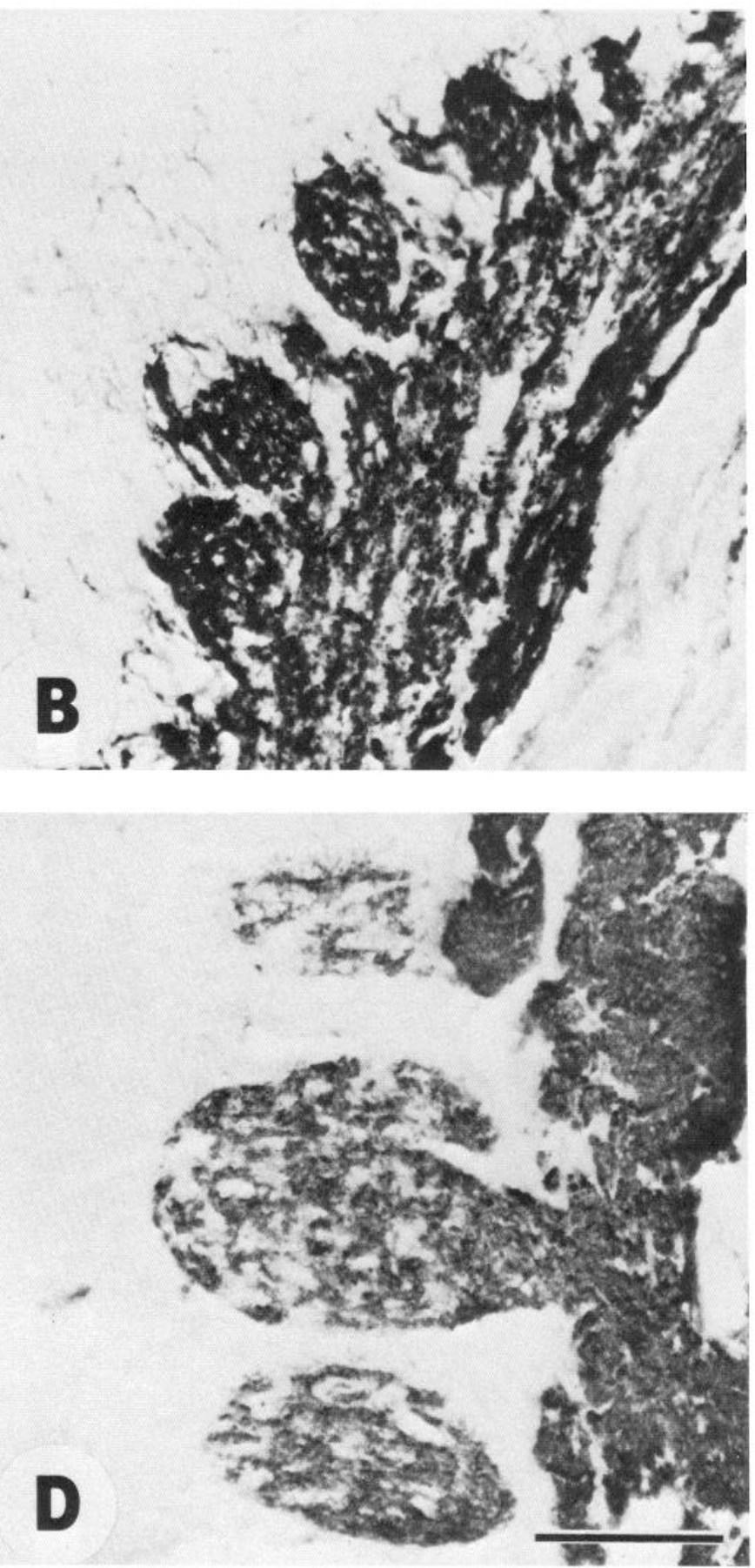

Figure 4. Localization of B50/GAP43 and OMP in the olfactory bulb glomeruli. B50/GAP43 $(A, C)$ and OMP $(B, D)$ immunostaining in a 3-dold $(A, B)$ and a 6-month-old $(C, D)$ rat. Note the increase in glomerular diameter and reduced B50/GAP43 staining in older rats. Scale bar, $50 \mu \mathrm{m}$.

layer. In the glomeruli at this age, small numbers of intensely stained punctae stood out against an otherwise faint background (Fig. 4).

\section{Discussion}

The molecular processes underlying the neurogenic properties of the olfactory neuroepithelium are poorly understood. This study focuses on the expression of the neuron-specific phosphoprotein B50/GAP43 in the olfactory epithelium of the postnatal and adult rat. B50/GAP43 is currently one of the best characterized markers of growing, developing, and regenerating neuronal processes (reviewed by Benowitz and Routtenberg, 1987). Antibodies against B50/GAP43 proved to be useful probes to distinguish between mature nongrowing axons and regenerating nerve fibers since B50/GAP43 levels in newly formed nerve fibers rapidly decline after these fibers have made connections with their target cells (Skene and Willard, 1981; Verhaagen et al., 1988a). This prompted us to study the expression of B50/GAP43 in olfactory neuron development and neural plasticity. 
The distribution of $\mathrm{B} 50 / \mathrm{GAP} 43$ is a function of both the age of the animal and the maturational state of the olfactory receptor neurons. In neonatal rats B50/GAP43 can be visualized throughout the population of olfactory receptors, including the cell bodies, dendritic knobs, proximal olfactory cilia, and axons of the receptor cells. Thus, at least in the olfactory system, the expression of this protein is not solely restricted to axonal processes and axon growth cones, as has been previously suggested (De Graan et al., 1985; Oestreicher and Gispen, 1986) but occurs in dendritic processes as well. In mature receptor neurons, as demonstrated by immunohistochemical staining for OMP, B50/GAP43 immunoreactivity is virtually absent (Fig. 1). In rats 3.5 and 6 months old, a small number of neurons whose cell bodies lie adjacent to the basal cell layer of the neuroepithelium express B50/GAP43 immunoreactivity (Figs. 1I, 2).

The olfactory nerve bundles and the glomeruli in the olfactory bulb are intensely stained in neonatal rats. However, with increasing age B50/GAP43 immunoreactivity in these structures declines so that in the older rats only a typical patchy staining pattern remains in the majority of nerve bundles, while punctae of immunoreactivity are present in the adult glomeruli (Fig. 4). Although it is likely that these punctae are foci of synaptogenesis displaycd by B50/GAP43-positive ingrowing fibers, it is possible that they reflect some other process involving B50/GAP43. $A$ recent study on the gross anatomical distribution of the $\mathrm{B} 50 /$ GAP43 throughout the CNS reported that B50/GAP43 mRNA and protein levels were higher in integrative and limbic brain structures relative to other brain areas. This was interpreted as indicating either a relationship between the appearance of this growth-associated protein and structural synaptic modification in adult animals or involvement of B50/GAP43 in other synaptic events, i.e., signal transduction (Neve et al., 1987; Benowitz et al., 1988). This view is supported by the demonstration that this protein is identical to a neural-specific calmodulinbinding protein (Cimler et al., 1987), indicating it could play a role in modulating a variety of calmodulin-regulated processes in brain.

To evaluate the expression of B50/GAP43 in the olfactory receptor cells, we employed antibodies against the only known specific marker of mature olfactory neurons, OMP. As development proceeds, the expression of the B50/GAP43 protein becomes progressively confined to those cell bodies adjacent to the basal lamina, while OMP-positive cells are primarily restricted to the upper compartment of the epithelium. The high levels of B50/GAP43 expression in the total population of olfactory receptor cells during the early postnatal stages of development corresponds to the demand for the production of new receptor neurons when both the surface area and thickness of the neuroepithelium are expanding. The observed reciprocal expression of B50/GAP43 and OMP during the development of the olfactory epithelium is consistent with the view that $\mathrm{B} 50 /$ GAP43 is a marker of ongoing neuronal growth, while OMP is an indicator of olfactory neuron maturity.

One of the most intriguing observations made in this study is the presence of B50/GAP43 in cells adjacent to the basal cell layer of the epithelium of the 3.5- and 6-month-old rats. This deep region of the olfactory epithelium is virtually devoid of OMP-containing cells but is known to contain newly formed differentiating receptor cells (Graziadei and Monti Graziadei, 1978; Farbman and Margolis, 1980). The presence of the growthassociated B50/GAP43 protein in cells located in this region of the epithelium of adult rats is therefore highly consistent with the ability of this tissue to manifest neuronal turnover during adulthood. The uneven distribution of B50/GAP43-positive cells adjacent to the basal portion of the epithelium may relate to the previously reported active and quiescent zones of ${ }^{3} \mathrm{H}$-thymidine incorporation in the basal cell layer of the epithelium (Graziadei and Monti Graziadei, 1979). Clearly, a combined study monitoring ${ }^{3} \mathrm{H}$-thymidine labeling and B50/GAP43 expression in the olfactory epithelium would be desirable. A similar pattern of ontogeny and uneven distribution of cells adjacent to the basal cell layer of the olfactory mucosa has been reported for the enzyme adenosine deaminase (Senba et al., 1987). The B50/GAP43-positive cells in the basal region of the neuroepithelium of the older rats exhibit both dendritic and neuritic processes, but the dendritic knobs seem devoid of cilia. Since their location suggests they are lacking OMP as well, they presumably belong to a population of neurons at an intermediate stage of maturation. Similarly, the patchy B50/GAP43 staining pattern in the nerve bundles of adult rats is probably due to the presence of newly formed neurites in the nerve bundles which are otherwise comprised of axons containing only very low levels of B50/GAP43 immunoreactivity. It is of interest to note that the B50/GAP43-immunoreactive areas in the nerve bundles seem to be comprised of groups of fibers suggesting that the outgrowing axons of a number of B50/GAP43-positive cells may collect from a given active zone and continue their growth together. A labeling pattern strikingly similar to the axonal B50/ GAP43 staining in adult rats was seen for OMP in nerve bundles of early postnatal rats (Fig. $3 B$ ). This is consistent with the presence of only a relatively small number of OMP-containing cell bodies in the neuroepithelium of early postnatal rats. Thus, the reciprocal expression of B50/GAP43 and OMP immunoreactivity observed in the cell bodies of olfactory neurons persists at the levels of the axons of the olfactory receptor cells.

The virtual absence of B50/GAP43-positive cells in epithelium of 7 -week-old rats (Fig. $1 G$ ) and their presence in 3.5- and 6-month-old rats is in agreement with the proposals of Hinds et al. (1984) and Breipohl et al. (1986). These investigators postulated that the rate of receptor cell turnover is not constant throughout the lifespan of the animal (as was suggested by Graziadei and Monti Graziadei, 1978) but varies with both the age of the animal and the environmental and nutritional condition in which the animals are reared. In support of this, Breipohl et al. (1986) observed a gradual increase in the number of immature receptor cells in older rats.

The presence of B50/GAP43 in immature but not mature olfactory neurons and its apparent absence from quiescent progenitor cells should make this protein a useful tool to identify subsets of primary olfactory neurons based on maturational stage. Creation of clonal cell lines of olfactory neuron progenitor cells has been a goal of several laboratories (Goldstein and Quinn, 1981; Schubert et al., 1985). A critical problem in such studies has been the absence of suitable markers for the unambiguous identification of immature olfactory neurons in dissociated cultures. Thus, various biochemical markers that could serve to identify olfactory neurons in culture have been shown to be preferentially expressed in mature rather than immature neurons. Among these are OMP (Farbman and Margolis, 1980), carnosine (Margolis, 1980), carnosine synthetase (Margolis et al., 1987), G-proteins (Anholt et al., 1987, Jones and Reed, 1987), peripheral benzodiazepine binding sites (Anholt et al., 1984), H- and B-blood cell antigens (Mollicone et al., 1985), 
and vimentin (Schwob et al., 1986). Neurofilament proteins, the classical neuronal marker proteins, are not present in olfactory neurons (Vollrath et al., 1985; Schwob et al., 1986). Monoclonal antibodies that have been shown to react with subsets of olfactory neurons (Allen and Akeson, 198.5a, $\mathbf{b}$; Hempstead and Morgan, 1985) may ultimately prove to be useful for this purpose. The presence of the neuron-specific B50/GAP43 protein in immature olfactory receptor neurons but not in quiescent progenitor cells, as described in this report, may facilitate the identification of putative immature olfactory neurons in primary cultures and in cloned olfactory cell lines.

In summary, we have demonstrated the expression of the neuron-specific, growth-related, calmodulin-binding, phosphoprotein B50/GAP43 in olfactory receptor neurons. The population of olfactory neurons expressing this phenotype alters during ontogeny in a manner that is essentially the reciprocal of that seen for OMP. The $\mathrm{B} 50 / \mathrm{GAP} 43$ protein is present throughout the receptor neuron, including the perikaryon, synaptic projections of these neurons in the olfactory bulb, the proximal portion of the olfactory cilia, the dendritic process, and the axon. Although B50/GAP43 is present in all olfactory neurons in neonatal animals, its distribution is progressively restricted to receptor neurons deep in the epithelium of young adult animals. Concurrently, the extent of B50/GAP43 staining declines in the axon bundles and in the glomerular layer in the olfactory bulb. In 3.5- and 6-month-old rats, B50/GAP43 is seen only in small clusters of immature neurons whose nuclei are located adjacent to the basal cell region. The dendrites of these positive neurons terminate in knobs at the epithelial surface but seem devoid of cilia, indicating that they are not yet functionally mature. The B50/GAP43-positive cells may be a population of cells held in reserve by the tissue for immediate response to replace cells lost as a result of environmental damage.

\section{References}

Allen, W. K., and R. Akeson (1985a) Identification of a cell surface glycoprotein family of olfactory receptor neurons with a monoclonal antibody. J. Neurosci. 5: 284-296.

Allen, W. K., and R. Akeson (1985b) Identification of an olfactory receptor neuron subclass: Cellular and molecular analysis during development. Dev. Biol. 109: 393-401.

Anholt, R. H., R. M. M. Murphy, G. Mack, and S. H. Snyder (1984) Peripheral type benzodiazepine receptors in the central nervous systems: Localization to olfactory nerves. J. Neurosci. 4: 593-603.

Anholt, R. M., S. M. Mumby, D. A. Stoffers, P. R. Girard, J. F. Kuo, and S. H. Snyder (1987) Transduction proteins of olfactory receptor cells: Identification of guanine nucleotide binding proteins and protein kinase C. Biochemistry 26: 788-795.

Basi, G. S., R. D. Jacobson, I. Virag, J. Schilling, and J. H. P. Skene (1987) Primary structure and transcriptional regulation of GAP43, a protein associated with nerve growth. Cell 49: 785-791.

Benowitz, L. I., and A. Routtenberg (1987) A membrane phosphoprotein associated with neural development, axonal regeneration, phospholipid metabolism and synaptic plasticity. Trends Neurosci. 10: 527-532.

Benowitz, L. I., M. G. Yoon, and E. R. Lewis (1981) Specific changes in rapidly transported proteins during regeneration of the goldfish optic nerve. J. Neurosci. I: 300-307.

Benowitz, L. I., P. J. Apostolides, N. Perrone-Bizzozero, S. P. Finkelstein, and H. Zwiers (1988) Anatomical distribution of the growthassociated protein GAP43/B50 in the adult rat brain. J. Neurosci. 8: 339-352.

Breipohl, W., A. Mackay-Sim, D. Grandt, B. Rehn, and C. Darrelman (1986) Neurogenesis in the vertebrate main olfactory epithelium. In Ontogeny of Olfaction, W. Breipohl, ed. pp. 21-34, Springer-Verlag, New York.
Chuah, M. I., A. I. Farbman, and B. Ph. M. Menco (1985) Influence of olfactory bulb on dendritic knob density of rat olfactory receptor neurons in vitro. Brain Res. 338: 259-266.

Cimler, B. M., D. H. Giebelhaus, B. T. Wakim, D. R. Storm, and R. T. Moon (1987) Characterization of murine cDNAs encoding P-57, a neural-specific calmodulin-binding protein. J. Biol. Chem. 262: $12158-12163$.

Costanzo, R. M., and Graziadei, P. P. C. (1983) A quantitative analysis of change in the olfactory epithelium following bulbectomy in the hamster. J. Comp. Neurol. 215: 370-381.

De Graan, P. N. E., C. O. M. Van Hooff, B. C. Tilly, A. B. Oestreicher, P. Schotman, and W. H. Gispen (1985) Phosphoprotein B-50 in nerve growth cones from fetal rat brain. Neurosci. Lett. 61: 235-241.

Farbman, A. I., and F. L. Margolis (1980) Olfactory marker protein during ontogeny: Immunohistochemical localization. Dev. Biol. 74: 205-215.

Fujita, S. C., K. Mori, K. Imamura, and K. Okata (1985) Subclass of olfactory receptor cells and their segregated central projections demonstrated by a monoclonal antibody. Brain Res. 326: 192-196.

Goldstein, N. I., and M. R. Quinn (1981) A novel cell line isolated from the murine olfactory mucosa. In Vitro 17: 593-598.

Graziadei, P. P. C., and G. A. Monti Graziadei (1978) The olfactory system: A model for the study of ncurogenesis and axon regeneration in mammals. In Neuronal Plasticity, C. W. Cotman, ed., Raven, New York.

Graziadei, P. P. C., and G. A. Monti Graziadei (1979) Neurogenesis and neuron regeneration in the olfactory systems of mammals. I. Morphological aspects of differentiation and structural organization of the olfactory sensory neurons. J. Neurocytol. $8: 1-18$.

Hempstead, J. L., and J. I. Morgan (1985) A panel of monoclonal antibodies to the rat olfactory epithelium. J. Neurosci. $5: 438-449$.

Hinds, J. W., P. L. Hinds, and N. A. McNelly (1984) An autoradiographic study of the mouse olfactory epithelium: Evidence for longlived receptors. Anat. Rec. 210: 375-383.

Jacobson, R. D., I. Virag, and J. H. P. Skene (1986) A protein associated with axon growth, GAP43, is widely distributed and developmentally regulated in rat CNS. J. Neurosci. 6: 1843-1855.

Jones, D. T., and R. R. Reed (1987) Molecular cloning of five GTPbinding protein cDNA species from rat olfactory neuroepithelium. $\mathrm{J}$. Biol. Chem. 262: 14241-14249.

Karns, L. R., S.-C. Ng, J. A. Freeman, and M. C. Fishman (1987) Cloning of complementary DNA for GAP 43, a neuronal growthrelated protein. Science 236: 597-600.

Keller, A., and F. L. Margolis (1975) Immunological studies of the rat olfactory marker protein. J. Neurochem. 24: 1101-1106.

Margolis, F. L. (1972) A brain protein unique to the olfactory bulb. Proc. Natl. Acad. Sci. USA 69: 1221-1224.

Margolis, F. L. (1980) Carnosine: An olfactory neuropeptide. In Role of Peptides in Neuronal Function, J. L. Barber and T. Smith, eds., Dekker, New York.

Margolis, F. L. (1988) Molecular cloning of olfactory specific gene products. In Molecular Neurobiology of the Olfactory System, F. L. Margolis and T. V. Getchell, eds., Plenum, New York.

Margolis, F. L., M. Grillo, J. Hempstead, and J. I. Morgan (1987) Monoclonal antibodies to mammalian carnosine synthetase. J. Neurochem. 48: 593-600.

McLean, I. W., and P. K. Nakane (1974) Periodate-lysine-paraformaldehyde fixative for immunoelectron microscopy. J. Histochem. Cytochem. 22: 1077-1083.

Meiri, K., K. Pfenninger, and M. Willard (1986) Growth-associated protein GAP43, a polypeptide that is induced when neurons extend axons, is a component of growth cones and corresponds to a major polypeptide enriched in growth cones. Proc. Natl. Acad. Sci. USA 83: 3537-3541.

Miragall, F., and G. A. Monti Graziadei (1982) Experimental studies on the olfactory marker protein. II. Appearance of the olfactory marker protein during differentiation of the olfactory sensory neurons of mouse: An immunohistochemical and autoradiographic study. Brain Res. 329: 245-250.

Mollicone, R., J. Trojan, and R. Oriol (1985) Appearance of H and B antigens in primary sensory cells of the rat olfactory apparatus and inner ear. Dev. Brain Res. 17: 275-279.

Neve, R. L., N. I. Perrone-Bízzozero, S. Finkelstein, H. Zwiers, E. Bird, D. M. Kurnit, and L. I Benowitz (1987) The neuronal growth associated protein GAP43 (B50, F1): Use of cDNAs to show the neu- 
ronal specificity, developmental regulation and regional distribution of the human and rat mRNAs. Mol. Brain Res. 2: 177-183.

Nielander, H. B., L. M. Schrama, A. J. Van Rozen, M. Kasperaitis, A. B. Oestreicher, P. N. E. De Graan, W. H. Gispen, and P. Schotman (1987) Primary structure of the neuron-specific phosphoprotein B50 is identical to growth associated protein GAP43. Neurosci. Res. Commun. 1: 163-172.

Oestreicher, A. B., and W. H. Gispen (1986) Comparison of the immunocytochemical distribution of the phosphoprotein B50 in the cerebellum and hippocampus of immature and adult rat. Brain Res. 375: 267-279.

Oestreicher, A. B., C. J. Van Dongen, H. Zwiers, and W. H. Gispen (1983) Affinity purified anti-B50 protein antibody: Interference with the function of the phosphoprotein B50 in synaptic plasma membranes. J. Neurochem. 41: 331-340.

Rosenthal, A., S. Y. Chan, W. Menzel, C. Haskell, W.-J. Kuang, E. Chen, J. N. Wilcox, A. Ullrich, D. V. Goeddel, and A. Routtenberg (1987) Primary structure and mRNA localization of protein $F_{1}$, a growth related protein kinase $C$ substrate associated with synaptic plasticity. EMBO J. 6: 3641-3646.

Samanen, D. W., and W. B. Forbes (1984) Replication and differentiation of olfactory receptor neurons following axotomy in the adult hamster: A morphometric analysis of post-natal neurogenesis. J. Comp. Neurol. 225: 201-211.

Schubert, O., W. Stallcup, M. La Corbiere, Y. Kidokomo, and L. Orgel (1985) The ontogeny of electrically excitable cells in cultured olfactory epithelium. Proc. Natl. Acad. Sci. USA 82: 7782-7786.

Schwob, J. E., N. B. Farber, and D. I. Gottlieb (1986) Neurons of the olfactory epithelium in adult rats contain vimentin. J. Neurosci. 6 : 208-217.
Senba, E., P. E. Daddona, and Y. I. Nagy (1987) Adenosine deaminasecontaining neurons in the olfactory system of the rat during development. Brain Res. Bull. 18: 635-648.

Skene, J. H. P., and M. Willard (1981) Changes in axonally transported proteins during regencration in toad retinal ganglion cells. J. Cell Biol. 89: $96-105$

Skene, J. H. P., R. O. Jacobson, W. J. Snipes, C. B. McGuire, J. J. Nordon, and J. A. Freeman (1986) A protein induced during nerve growth (GAP43) is a major component of growth-cone membranes. Science 233: 763-768.

Van Hooff, C. O. M., P. N. E. De Graan, J. Boonstra, A. B. Oestreicher, M. V. Schmidt-Michels, and W. H. Gispen (1986) Nerve growth factor enhances the level of the protein kinase C substrate B-50 in pheochromocytoma PC- 12 cells. Biochem. Biophys. Res. Commun. 2: 644-651.

Verhaagen, J., C. O. M. Van Hooff, P. M. Edwards, P. N. E. De Graan, A. B. Oestreicher, P. Schotman, F. G. I. Jennekens, and W. H. Gispen (1986) The kinase C substrate protein B50 and axonal regeneration. Brain Res. Bull. 17: 737-741.

Verhaagen, J., A. B. Oestreicher, P. M. Edwards, H. Veldman, F. G. I. Jennekens, and W. H. Gispen (1988a) Light and electromicroscopical study of phosphoprotein B-50 following denervation and reinnervation of the rat soleus muscle. J. Neurosci. 8: 1759-1766.

Verhaagen, J., A. B. Oestreicher, W. H. Gispen, and F. L. Margolis (1988b) B50 expression in the basal cell layer of the mature olfactory epithelium. Trans. Am. Soc. Neurochem. 19: 305.

Vollirath, M., M. Altmainsberger, K. Weber, and M. Osborn (1985) An ultrastructural and immunohistological study of the rat olfactory epithelium: Unique properties of olfactory sensory cells. Differentiation 29: 243-253. 